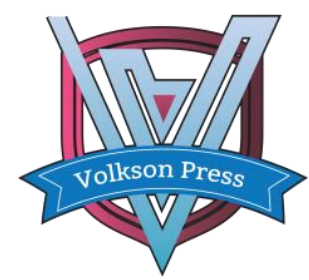

Contents List available at VOLKSON PRESS

Economics \& Management Innovations(EMI)

DOI : http://doi.org/10.26480/icemi.01.2017.316.319

\title{
Integration of organizational culture for company's customers and employees
}

\author{
Katarzyna Świerszcz \\ Military University of Technology, Warsaw, Faculty of Logistics ul. gen. Sylwestra Kaliskiego 2, 00-908 Warsaw, Poland \\ email: katarzyna.swierszcz@wat.edu.pl
}

This is an open access article distributed under the Creative Commons Attribution License, which permits unrestricted use, distribution, and reproduction in any medium, provided the original work is properly cited.

\section{ARTICLE DETAILS}

\section{Article History:}

Received 02 october 2017 Accepted 06 october 2017 Available online 11 october 2017

\section{Keywords:}

organizational

culture, integration, employee, customer, creative

\section{ABSTRACT}

This article attempts to analyze the importance and definition of an integral approach to an organizational culture that should be applied to both the employee and the customer. This issue has been considered on the basis of many studies, observations, and interviews with business executives, their employees and customers. With reference to them, it can be easily seen that in the new dynamically changing market, where the companies are oriented not only on efficiency, but also on modernization and even survival, a lot of them lose half of their customers within five years, half of their employees within four years and half of their investors within less than a year. This disturbing phenomenon clearly requires the need or even the necessity to understand the organizational culture in a new way concerning its integral aspect created by relationship built on three levels: company vs. employee, company vs. customer and employee vs. customer. An integral approach to the culture is so important as it is a set of values and norms of conduct that are the source of energy and a stimulator of company's activities aimed to reach its particular objective and at the same time a basic factor to fulfill its mission and implement the strategy of improving its business effectiveness. Moreover, the culture represents identity of company, affects its image and strengthens its reputation.

Therefore, the subject of this paper is presented in three aspects:

- Integration of customer-oriented organizational culture;

- Integration of employee-oriented organizational culture;

- $\quad$ Employee orientation to customer needs.

To study the problem more deeply, the research was carried out using survey and analytical-synthetic methods.

\section{Introduction}

It is not an easy task to clearly define the term "organizational culture". The way we understand it mostly depends on three issues: the concept it reflects, the author's approach and the matter of focus. In general, this concept may be described as a set of dominant values and standards of conduct that are characteristic for a particular organization, built on the assumptions of the nature of reality, expressed through artifacts, e.i. external artificial creations of a given culture [1]. Based on conducted research, the organizational culture may be defined as a set of beliefs developed in the course of company's business while solving its various internal problems with integration and adapting to external market conditions. This definition of organizational culture includes a set of rules that become unwritten law and are provided to employees as the right way of thinking, feeling and acting. Above meaning of organizational culture suggests that this is a form and expression of the company's personality. But this raises the question: What is the essence of a mature personality, i.e. organizational culture of the company today? Is it: just "to have" or maybe also "to be"? The research of the market in a wide sense shows that currently many companies lose half of their customers within five years, half of their employees within four years and half of their investors within less than a year. Therefore, will the organizational culture of the company be in the future merely an opportunistic transaction between people completely strange to each other? Is it really time to give up hope and accept the world of fast money speculators, of careerists passing from company to company, of "disposable" employees and capricious customers? Finally, the most important question: Do companies have a chance to succeed if their organizational culture is based on opportunism? In this article I will try to present answers to these questions.

\section{Integration of customer-oriented organizational culture}

As never before, today customer-oriented organizational culture of a company forms at the same time essential foundation and challenge both for effective creation and management of customer's satisfaction and loyalty. The process of creating and developing a customer-oriented culture begins with the founder of the company, who defines the mission, it means, a declaration about the essence and scope of the company's business, and defines its vision. The mission should be understandable for both employees and customers as well as for the rest of the environment. It should include recommendation for opportunities or even the need to build and maintain the most relevant values to the company, i.e. customer satisfaction and loyalty. These recommendations shall be formulated clearly and precisely, not abstractly or wishfully. It provides everyone with a clear message about what is really the greatest value for the company. This is shown in Fig. 1.

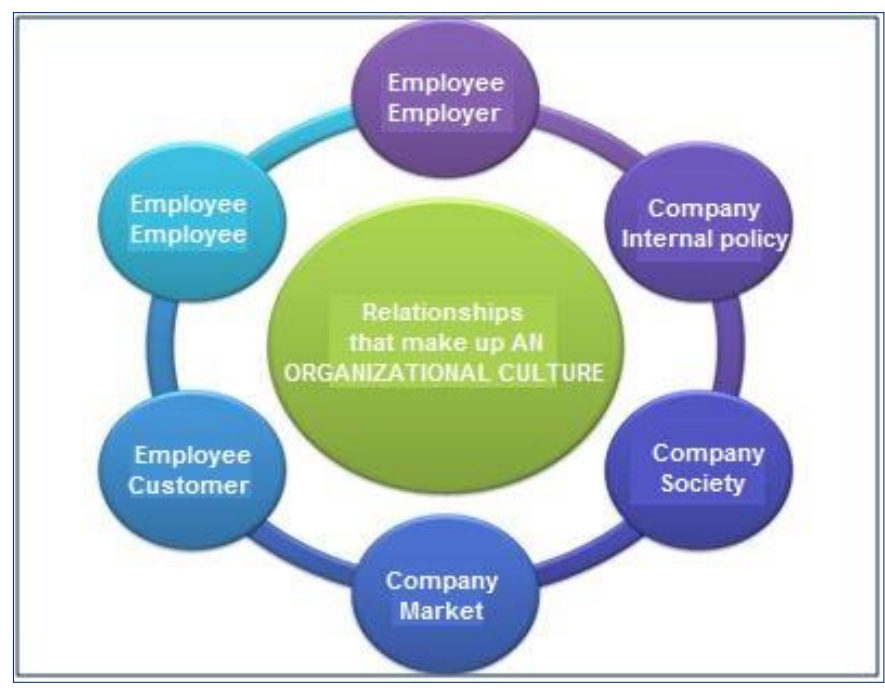

Figure 1. COMPONENTS OF COMPANY'S ORGANIZATIONAL CULTURE

Source: own author's ellaboration.

Based on conducted research, one of the reasons why so many today's 
companies are failing is that they measure, analyze, and learn about profit figures rather than the process of value creation. Management sees problems only when profits decrease and, trying to improve the situation, they concentrate on symptoms rather than on the decomposition of the system that creates value for the recipient. We can dare to say that customers are often treated as only profit-giving and that therefore the care of them is forwarded to marketing departments while customer satisfaction and loyalty are too important to appoint this care to "someone else", i.e. to created - sometimes artificially - a separate (dedicated for this purpose) company's divisions. Building strong customer relationships should be a particular concern for the whole company. Therefore, the development of a corporate customer-oriented culture strategy does not require the need to create special departments for research or increasing customer satisfaction. To confirm that, there are many companies that have a high customer satisfaction rate and in which there is no separate department for these matters. In these companies customer satisfaction is the highest value for all employees serving customers. Research among companies, such as Poczta Polska S.A., CARGOSPED Sp. z o.o., LOT Polish Airlines and related customers shows that in companies where the responsibility for customer satisfaction lies with the customer service department or customer satisfaction department rather than with the organizational culture of the company - the quality is never satisfactory. What is more, there is an inverse relationship between the size of the customer service department and the level of service provided. The conducted customer satisfaction survey leads to the conclusion that customer service is too important to just leave it for people responsible for so-called "consumer relation" as it has a crucial influence on every element and aspect of the company's business structure. Therefore, we can say for sure that the responsibility for maintaining good relations with customer is the responsibility of the entire company and in particular company's directors.

As market research shows, the need to humanize company's organizational culture that is expressed in customer orientation, i.e. customer satisfaction and loyalty, enables the company to achieve high levels of customer retention, which then provides a great competitive advantage and, what also matters, improves morale of employees, increases their motivation and pride, discovers unforeseen surpluses in production and development and offers the opportunity to reduce the cost of capital. Thus, orientation to customer, meaning delivering him value and perceiving him as a value, is the foundation of the organizational culture of every successful business. The economic reality too clearly shows that the profit which until recently - and even still - has been placed in the centre in the conventional, short-sighted, one-dimensional way of thinking about a business organization, so called "economic" logic or economic "rationality", is not an element of primary importance. It is obvious that profit-making is necessary, but as a natural consequence of the value creation which together with loyalty are the core of every stable business.

The strategy of organizational culture oriented for no loss of loyalty implies a different theory of this culture (business culture). The old way of understanding can be called the theory of profit culture, in which all the skills of creating organizational culture and competencies are subordinated to profit generation. The new humanized theory of organizational culture strategy sees the company's mission not in profit but in value creation. Profit is considered as a necessary consequence (regularity) of creating value, as a means and not a goal, as a result and not an intention. Moreover, paradoxically, the theory of value creation helps to join often divergent points of view of company management, employees, customers, investors and many others. It should also be noted and emphasized that the above value creation theory, which is an innovation of an integral organizational culture, also makes loyalty and satisfaction a more reliable criterion and test of a properly managed company and its performance, than it has ever been before when it comes to profit (thought to be the only reliable criterion)[2]. It turns out that profits themselves are the unreliable indicators, because it is possible to increase obvious profits - which are short-term - at the expense of human capital. Lowering the quality of products, values delivered to the market, decreasing salaries or wages, raising prices and many other actions taken in this direction may generate revenue growth, but at the same time they are not indifferent to customer and employees behavior as they have a negative influence on customers' loyalty and thus reduce the value and time of operation of these resources [3]

When we talk about the innovation of an integral corporate culture oriented to customer's loyalty, we may get the impression that loyalty and profit are contradictory, in conflict. However, this alleged conflict is only a misunderstanding. In order to solve it, we must reject the short-sighted mentality and note that there are two kinds of profits. The first one is a creative profit achieved by the company through value creation and its sharing, which means creation of the humanism of organizational culture. The second one is a destructive profit which results from the exploitation of company resources and the resale of its actual balance at a discounted price. This kind of profit is treated as a goal in itself. It is a profit (value) only to the shareholders. This profit undermines the company's reputation and consequently effectively shortens its average operating life [4]. This approach to profit results from the fact that many business executives have adopted the wrong paradigm, whose essence is contradictory to the integrity of the corporate culture regarding to the management of value and loyalty. It seems that the current concept of the profit-oriented business world is equally distorted and has the effect opposite to the intentions of geocentric theory. However, once again, it does not mean that profit does not matter. Determining the right position of the Sun did not make the Earth less important and the Sun more. It only helped to understand the mechanics. Profit does not have to and simply should not be placed in the centre of the business solar system to be indispensable. So, as we can see, a proper understanding of the business nature, its integral organizational culture as well as the determination of the right position and the relationship between profit, value and loyalty enable to understand the mechanics, which is the basis of the company existence and activity [5]. What is more, the economics of this ethical business philosophy shows its extraordinary attractiveness. Unfortunately, many companies are still unable to see this attractiveness based on dependence that joins value, loyalty and long-term profitability - transforming loyalty management in organizational culture into a philosophy that is used to make everyday decisions.

\section{Integration of employee-oriented organizational culture}

The customer-oriented corporate culture is inseparably related to the employee-oriented organizational culture. This natural order results from the cause-and-effect relationship between those two elements. The existing correlation clearly shows that you can not really treat customer loyalty without exploring employee loyalty. In other words, it is impossible to shape and maintain loyal customers without shaping and maintaining employee loyalty [6]. The research conducted among companies shows that more and more of them are aware that steel loyal employees have a decisive influence on the loyalty of their customers. Good relationships with customers have their origin in good relationships with employees. The loyalty of customers is particularly influenced by the so-called linear employees being in direct relationship with the customer This is just through them, not through company management how the customers contact the company. Their loyalty is the greater, the greater is their relation with the service personnel. The line workers are those who build trust with the customers and shape their expectations. The customer who is regularly serviced by one employee - trusts him or her, starts to count on his/her help in decision-making while purchasing a product or using a service. So when the employees leave, the customers often leaves with them too [7].

A common phenomenon that can be observed in a company is a reduction of its own economic potential by adopting inadequate personnel policies leading to employee dissatisfaction and, consequently, contributing to a high rate of fluctuations. This is the effect of company disability to assess long term benefits resulting from applying measures aimed to maintain and develop the staff, i.e. to adopt a loyalty attitude towards employees. The company's management often declares they care about employee's loyalty, but when it comes to increasing the renumeration, their belief in the validity of such a human resources policy is usually decreased. For instance, they doubt in the principle that if the salary increases by $25 \%$, the employee fluctuation rate decreases by $5 \%$. On this basis we can say that the company management often adopts a stance of "knowing the price of everything but value of nothing". Knowing how much money the employees cost but not how much they are worth is not only a sign of cynicism, but also a serious brake on the company's growth and competitiveness.

Nowadays, in times of economic turmoil, the corporate culture of many companies is filled with the atmosphere in which the management is not interested in concentrating on finding ways to maintain employees for a longer time and to help them make more money. It can often be seen that the goal is quite opposite: looking for ways to pay employee as little as possible or dismiss him/her - paradoxically it often applies to an employee with the richest experience and the highest renumeration. Employee's often response to such experience is an attitude in which he/she concludes that being absolute committed and loyal to the company is just unprofitable. Lack of loyalty and sense of security is replaced by lack of trust, creativity and anxiety. Such built organizational culture often reminds frightened and bitter employees who working more and more often see only one thing - the salary. The relationship between the staff and employers increasingly relies on mutual exploitation. Additionally one 
more fact is also important. Namely, more and more companies resemble nomadic tribes, who, simply bearing in mind profits, not honesty, creativity and employee loyalty, "pitch their tents" for a while and go further in a moment chasing the profit, looking for cheaper and cheaper labor. Such a philosophy of organizational culture may seem a sensible answer, especially in times of increasing anxiety and confusion in the business world. This answer provides the vision of the dynamic flexibility and risky energy that may be extremely attractive. However, it can be easily seen that nomadic tribes have made very little progress compared to large civilizations having institutions, scientific disciplines and the ability to face changes from a stable base [8].

The above considerations, confirmed by numerous studies and careful observation of the market, clearly present the urgent need to humanize the organizational culture of an employee-oriented company. Its activity should be based, among others, on:

\section{$>$ Creating a good image of the employer, \\ $>$ Applying the policy of proper selection and adaptation of employees, \\ $>$ Identifying the company's growth strategy by its employees, \\ $>$ Motivating employees and affecting them with a variety of techniques to build loyalty, \\ $>$ Forecasting the employment of new personnel, \\ $>$ Staff training, \\ $>$ Assessment of staff activities, \\ $>$ Introducing loyalty programs}

These actions in the form of an integrated organizational culture model oriented to employee are shown in Fig. 2.

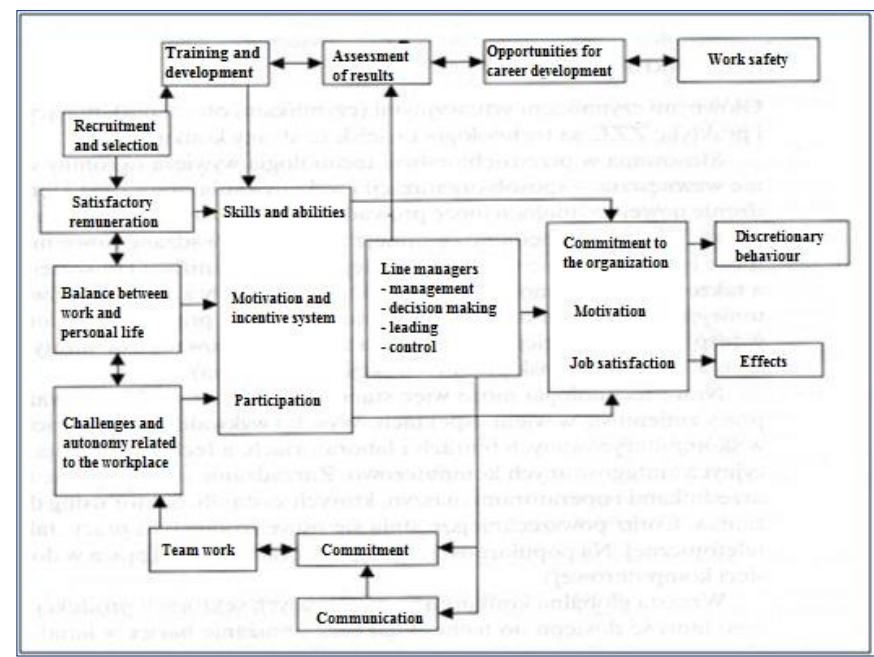

Figure 2. A MODEL OF AN INTEGRATED EMPLOYEE-ORIENTED ORGANIZATIONAL CULTURE

Source: M. Armstrong. (2007). Cracow. Zarządzanie zasobami ludzkimi, Oficyna a Wolters Kluwer business, p. 41.

\section{Employee orientation to customer needs}

An important element of the innovation of an integral organizational culture is the employee orientation to customer needs. Each employee must feel responsible for the customer: his/her needs and problems. Good customer service and care may only be assured if the employees are enabled to recognize customer needs on their own and in a flexible manner. The employee who interacts with the customer is solely responsible for him/her. This is so-called the "ownership" idea which the ultimate goal is total customer satisfaction. The decentralization of responsibility (so-called management-by-delegation) that is related to the above, assumes the creation of such an organizational structure that will define new duties and responsibilities for the employee, taking into account the value assessment system of customer satisfaction and loyalty [9].

As research and numerous observations show, employee's orientation to customer needs is more important than the company's product itself. That is why the customer service personnel should remember to:

$\checkmark \quad$ Spend the right amount of time with the customer;

$\checkmark \quad$ Answer questions instead of sending the customer to the leaflets; $\checkmark \quad$ Reduce customer's lack of trust in the company;

$\checkmark \quad$ Enable customer's decision-making while controlling the situation;

$\checkmark \quad$ Keep regular contact with the customer;

$\checkmark \quad$ Meet customer's needs.

Some situations are unacceptable and very poorly perceived by the customer. These are:

\section{$\checkmark \quad$ No interest in the customer;}

$\checkmark$ Customer treated by the employee as a problem (disturbance);

$\checkmark \quad$ An employee who does not listen, only "surfs the net";

$\checkmark \quad$ Treating a regular customer (client) as a necessary evil and dealing exclusively with new customers;

$\checkmark$ Applying the principle of "you buy nothing, then goodbye".

The customer should be served in such a way that when leaving the company he or she should feel satisfied with the service and have concerns about company's products reduced. Thus, the service should be personal. [10]. Such understood service enables to achieve the so-called "satisfaction triangle" which is composed of procedural, substantive and psychological factors as shown in Fig. 3.

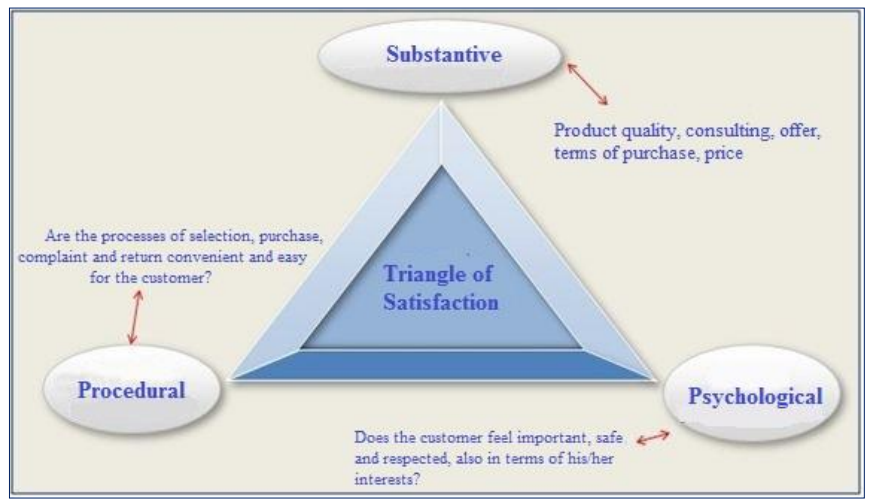

Figure 3. SATISFACTION TRIANGLE FOR THE CUSTOMER DEVELOPED BY AN EMPLOYEE

Source: own author's ellaboration.

The proper customer service also requires time. The time spent with the customer should also bring satisfaction to the employee. However, to do so, the company should employ enough staff so that they can speak freely with each and every customer. During the conversation employee should not urge the customer to choose the product or service. When the customer is considering an offer, he/she should have an employee at his/her disposal ready to answer all additional questions. In the case of indecision, an employee may always suggest a product, but keep in mind that the last decision shall be made by the customer [11].

Employee's orientation to the customer requires giving him/her complete attention. In other words, the customer may not be treated as an unnecessary obligation. Thus, it is unacceptable that while serving the customer the employee additionally receives a phone call, runs a computer, or conducts conversations with other employees on noncustomer-related topics. The employees' attention, especially of the employees from the first line, should be focused solely on the customer as the customer and his/her needs cannot be known well without giving $\mathrm{him} / \mathrm{her}$ enough attention. It is also unacceptable to neglect a regular customer (client) for a new one. Meanwhile, as research shows, employees often receive an additional remuneration for selling the product to a new customer. In such a situation, the customer is feeling redundant and does not have the motivation to be a loyal customer.

When we talk about an important role of employee's orientation to the customer, it means quality of customer service, we should pay attention to the importance of customer positive experiences in the service. Based on interviews with customers and their observations, it can be noticed that two negative experiences are enough to make an enemy from a friend. A man who was disappointed twice will have serious internal objections to give the next chance to fix the mistake.

However, many companies still underestimate the role of quality customer service in building and developing long-term relationships with them, concentrating only on product quality and sales process. While in the time of the qualitative revolution, initiated with the development of the Total Quality Management (TQM), and limited product diversification, it turns 
out that it is the customer service, being the last stage of the sales cycle, what has the most impact on the added value perceived by the customer contributing mostly to his/her satisfaction [12]. What is more, in order to maintain and develop this satisfaction, the company should plan strategies for dealing with customers in line with the evolution of the relationship with the customer. The engagement of the sellers should be the greatest just before the sale and for some time after its execution, and properly trained employees with appropriate approach should be able to assist their customers - owners of purchased products during the use.

It should also be emphasized that the satisfaction generated by the quality of customer service favors the creation of trust. This value refers to the relationship between the two parties making the transaction. It creates a special kind of relationship between the employee and the customer that together affects the value perceived by the customer. In addition, this particular kind of trust-based relationship encourages - if necessary - the search for solutions acceptable to both parties [13].

Customer trust in the employee, and thanks to him to the company, is a priority factor determining the occurrence, the correct course and the positive end of the relationship. Customer trust in the employee and consequently in the company consists of three types of trust [14]

- $\quad$ Calculated trust

- Institutional trust

- Personal trust

The calculated trust is based on the logical, rational arguments such as the experience of co-operation with a given employee, the possibility of profitability for both parties resulting from the undertaken economic activities, and the possibility of further cooperation with a given contractor. This trust also arises as a result of systematic targeting to the customer various types of advertising information, as well as information about ongoing tests, studies, certificates, quality certificates and many more.

Institutional trust relates to the institutional, organizational and social systems. It involves various types of economic contracts. Institutional trust is governed by existing legislation applicable in a particular country and by consumer protection organizations, protecting also consumer organizations, as well as by the local judicial system and control bodies. Personal trust is based primarily on the positive impressions, experiences, and emotions of the customer toward the company.

The above-mentioned factors that affect customer trust together with the three types of trust are the foundation of emotional relationships with customer and bring him/her both rational and emotional loyalty exceeding those rational preferences resulting from analysis of the offer. This loyalty is so important because it creates a strong bond between the customer and the company and makes it easier to maintain the customer. In addition, they are the foundation for creating a lasting economic relationship between the customer and the company [15].

\section{Conclusions}

Organizational culture is an important element of a company's strategy. It comprises of a number of values aimed at the good, i.e. the satisfaction and loyalty, of all employers, customers and employees. This personalization, it means faithfulness to humanistic values, is not a substitute for profit. On the contrary, it is an indispensable element of the strategy that companies should apply to achieve extraordinary levels of development and profitability.
The economic reality shows that many companies still do not understand the economics of organizational culture built on mutual satisfaction and loyalty between employer, customer and employee. The old way of understanding can be called the theory of profit culture, in which all the skills of creating organizational culture and competencies are subordinated to profit generation.

The new humanized theory of integral organizational culture seeks company's mission not in profit but in value creation. Paradoxically, they help to join often divergent points of view of company management, employees, customers, investors and many others. Moreover, it makes loyalty and satisfaction a more reliable criterion and a test of a properly managed business and its performance, than it has ever been done before when it comes to the profit.

\section{References}

[1] Ł. Sułkowski, M. Bednarek, A. Parkes, Kulturowa zmienność systemów zarządzania, Difin, Warszawa (2016).

[2] L. Zbiegień-Maciąg, Kultura w organizacji. Identyfikacja kultur znanych firm, PWN, Warszawa (2013).

[3] R. Kozielski, Biznes nowych możliwości czterolistna koniczyna - nowy paradygmat biznesu, Wydawnictwo Nieoczywiste, Warszawa (2017).

[4] K. Tobór-Osadnik, Wybrane zagadnienia zachowań organizacyjnych. Podręcznik z

ćwiczeniami, Politechnika Śląska, Śląsk (2016).

[5] B. Zatwarnicka-Madura, A. Pacana, L. Bednarova, Wybrane zagadnienia zarządzania, Politechnika Rzeszowska, Rzeszów (2016).

[6] A. Kołodziej-Durnaś, System społeczny firmy o historii kulturze i otoczeniu przedsiębiorstwa Dobosz, Economicus, Szczecin (2015).

[7] Ł. Sułkowski, Cz. Sikorski, Metody zarządzania kulturą organizacyjną, Difin, Warszawa (2014).

[8] M. A. Leśniewski, S. Morawska, Zasoby ludzkie w organizacji, CeDeWu, Warszawa (2012).

[9] Cz. Sikorski, J. Bieńkowska, Ewolucja zarządzania. Dyktat struktury strategii i kultury, Uniwersytet Łódzki, Łódź (2016).

[10] A. Sitko-Lutek, Kompetencje i kultura organizacyjna przedsiębiorstw w perspektywie

międzynarodowej, UMCS, Lublin (2014).

[11] R. Wolniak, Wymiary kulturowe Polskich organizacji a doskonalenie zarządzania jakością, CeDeWu, Warszawa (2012).

[12] A. Parkes, Kulturowe uwarunkowania lean management, Difin, Warszawa (2017).

[13] L. Hawrycz, Niematerialne czynniki konstytuujące systemy zarządzania oparte na jakości w organizacjach sektora publicznego, Difin, Warszawa (2014).

[14] A. Kisil, Zarzadzanie przez odpowiedzialność. Podstawa odpowiedzialnego biznesu, Difin, Warszawa (2013).

[15] M. Noga, Kultura a ekonomia, CeDeWu, Warszawa (2014). 